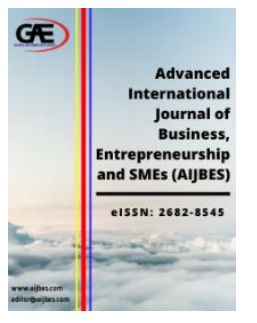

\author{
ADVANCED INTERNATIONAL JOURNAL OF \\ BUSINESS, ENTREPRENEURSHIP AND SMES \\ (AIJBES) \\ WWW.aijbes.com
}

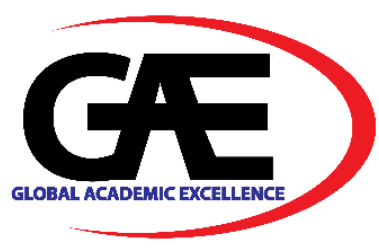

\title{
IMPACT OF JUSTICE IN EMPLOYEE PERFORMANCE AND MODERATING ROLE OF ARTIFICIAL INTELLIGENCE: A CONCEPTUAL STUDY
}

\author{
Marina Jokim Robert ${ }^{*}$, Yashar Salamzadeh ${ }^{2}$, Noor Fareen Abdul Rahim ${ }^{3}$ \\ 1 Graduate School of Business, Universiti Sains Malaysia, Penang. \\ Email: marina_jokim@ @otmail.com \\ 2 Senior Lecturer, Graduate School of Business, Universiti Sains Malaysia, Penang. \\ Email: yashar@usm.my \\ 3 Senior Lecturer, Graduate School of Business, Universiti Sains Malaysia, Penang. \\ Email: noorfareen@usm.my \\ Corresponding Author
}

\section{Article Info:}

Article history:

Received date: 30.10 .2021

Revised date: 18.11 .2021

Accepted date: 29.11.2021

Published date: 01.12.2021

To cite this document:

Robert, M. J., Salamzadeh, Y., \& Rahim, N. F. A. (2021). Impact of Justice in Employee Performance: Moderating Role of Artificial Intelligence. Advanced International Journal of Business, Entrepreneurship and SMEs, 3 (10), $39-48$.

DOI: $10.35631 /$ AIJBES.310004.

This work is licensed under CC BY 4.0

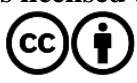

Abstract:

This study investigates the impact of justice's dimensions: distributive justice, procedural justice, interactional justice on performance appraisal satisfaction, and artificial intelligence utilisation to improve employee performance in Penang multinational companies (MNCs). They are grounded with Organizational Justice Theory as the theoretical framework to examine the relationship between Artificial Intelligence utilisation in enhancing justice to improve employee performance. In conducting this study, the required data will be collected through a closed-ended structured questionnaire in Penang, Malaysia. The questionnaire was adopted and adapted from many related studies. The data collection approach for this research is based on internetbased technologies such as online platforms. This paper proposes ways of managing employee performance by boosting performance appraisal satisfaction based on a practical performance appraisal that is relevant and unbiased. The paper will provide novelty into justice in performance appraisal through artificial intelligence that is pivotal to the employee performance optimisation in Penang multinational companies. The paper will help organisations recognise the significance of enhancing the performance appraisal as a practical strategic approach to integrate human resource activities with business policies and provide a better understanding of the impact of justice to the performance appraisal in the Penang multinational companies (MNCs). 
Keywords:

Distributive Justice, Procedural Justice, Interactional Justice, Employee

Performance, Performance Appraisal Satisfaction, Artificial Intelligence

\section{Introduction}

With the growing pace of globalisation, competition on a global scale among companies has become increasingly intense (Chabowski \& Mena, 2017). The organisation's workforce plays a dynamic role in achieving its goals (Rana et al., 2019)and good human resources management strategies can also affect its success (Shaukat et al., 2015). Therefore, organisations need to emphasise the factors that will enhance employees' performance and adopt practical ways to achieve and deliver higher job performance. Sandhu et al. (2017) stressed that employee performance fundamentally depends on factors like performance appraisals, compensation, training and development. However, if employees have been experiencing unfair treatment, they are more likely to demonstrate lower commitment levels and even start behaving in antinormative ways (Colquitt \& Zipay, 2015). Thus, understanding what people judge as just and fair is a significant issue for understanding employee behaviour. But how do people consider something to be fair or unfair? Roberson \& Stewart (2006) revealed a well-designed and fair performance appraisal system could attract, motivate, and improve employee performance.

According to Kuvaas (2006), many organisations express dissatisfaction with their appraisal scheme. A study by Rahahleh et al. (2019) disclosed that organisations are experiencing low performance because performance appraisals are not well managed. It is parallel with Ekom Etim et al. (2018), which revealed favouritism and biasness among the supervisors, lack of objectivity during the assessment, lack of continuous documentation, and inability to provide on-time feedback in their performance appraisal system. It results in employee dissatisfaction with the appraisal process (Agyare et al., 2016). It can further be linked to adverse employee outcomes such as higher turnover intention and lower commitment levels, negatively affecting employee performance (Kim \& Holzer, 2016). It is further supported by Warokka et al. (2012) that the employee's perception of justice is the ultimate check for the success of the performance appraisal system.

Studies also demonstrated that discrimination could occur due to the colour of the skin, gender, age, height, weight, the choice of religion (Dundon \& Rafferty, 2018), a disability status (Potgieter et al., 2017), or even where an individual received their education. In the Malaysian context, Abdul Wahab (2018) reported that Malaysia has continuing gender inequality, with women accounting for 49.3 per cent of the population and males accounting for 77.3 per cent. Unequal pay is still pervasive, with women earning less than men in all occupational sectors. In another study conducted by Hashim et al. (2015) reported that managers in a multinational firm in Malaysia lowered their employees' ratings and informed their staff that they had recommended a higher grade. Despite this, the staff's rating was downgraded following the calibration meeting, causing dissatisfaction among their manager. A recently published review reported a Human Resource Management Society survey indicated that 95 per cent of employees were not satisfied with the performance appraisal system implemented by the organisation (M. Shanmugam, 2019). Furthermore, Rasiah \& Krishnan (2020) emphasised that the country needs a strict appraisal mechanism to control poor performance. 


\section{Literature Review}

There will be four components discussed in the literature review.

\section{Organisational Justice Theory}

Organisational justice theory is termed as people's conceptions of fairness in organisations and the behavioural, cognitive, and emotional responses that go along with them (Greenberg, 1987). The three constructs of organisational justice theory that are widely acknowledged as follows: distributive justice, which relates to the results received; procedural justice, involving to the decision-making procedures that led to those outcomes; and interactional justice, which includes interpersonal and informational fairness (Bies \& Shapiro, 1987; Colquitt, 2001). Cropanzano et al. (2007) explain that employees examine justice concerning the distribution of outcomes, procedural allocation mechanisms, and human interactions. This theory is one of the leading research foci in organizational behaviour, industrial psychology and human resources (Cojuharenco \& Patient, 2013).

Distributive justice focuses on allocating work rewards proportionate to work inputs (Niehoff \& Moorman, 1993). It includes a sense of fairness in assigning organisational resources, such as wages, bonuses, and terminations, as well as any other resource that an organisation can provide to employees (Roch et al., 2019). In contrast, procedural justice represents fair formal procedures. The presence or absence of processes is crucial to the equitable distribution of rewards and is intended to boost employee voice in decisions or reduce bias and error in judgments(Niehoff \& Moorman, 1993). Voice, consistency, correctness, bias suppression, and correctability are aspects of procedural fairness that demonstrate appropriateness in decisionmaking processes (Colquitt \& Zipay, 2015). Lastly, Bies \& Shapiro (1987) characterised interactional justice as the fairness of an employee's treatment when executing formal procedures or handling an employee while a process is being performed out (Niehoff \& Moorman, 1993). Colquitt (2012) further added interactional justice occurs when relevant authorities convey procedural details courteously and adequately and justify choices with honest and genuine information. As a result, organizational justice theory affects the performance appraisal satisfaction perspective either negatively or positively.

\section{Impact of Justice on Performance Appraisal Satisfaction}

The effectiveness of the performance appraisal depends on its association with the perception of justice (Warokka et al., 2012). Suppose employees find the results of their assessments fair or find the mechanism by which decisions are generated about the distribution of results is acceptable. In that case, they are likely to reciprocate by engaging in behaviours that benefit their organisation. Pieces of literature posit that satisfaction with the performance evaluation is theoretically linked to fair assessment, thus determining workers' acceptance of the appraisal (Greenberg, 1986). Tomczak et al. (2018) stated that employees accept and see decisions as fair when transparent about setting policies and procedures in their systems to promotions. In addition, Krishnan et al. (2018) asserted that employees would then decide whether the outcome they received was just and the managerial decisions were accurate. Furthermore, establishing justice is an important managerial characteristic of an organisations since it promotes individuals' absorption in their obligations and organisations (Bobocel, 2021).

The issue of injustice and dissatisfaction in performance appraisal is a prevailing concern, leading the researcher to propose the framework and conduct this investigation. Justice and satisfaction in the performance appraisal are central as they influence the attitudes and 
Volume 3 Issue 10 (December 2021) PP. 39-48 DOI 10.35631/AIJBES.310004

behaviour of employees at work. Positive behaviours and actions will be projected if they are regarded as just acts, but negative behaviours or activities will be interpreted as unjust. It has been a high priority for management to develop an effective and sound performance appraisal system because it links with its goal attainment. Unfortunately, most organisations' current appraisal procedure is outdated as it is based on the bell curve scoring system, in which only the best 10 per cent of staff are rewarded (Shanmugam, 2019). Buck \& Morrow (2018) mentioned that an increasing multitude of businesses recognises the necessity for continual touchpoints and real-time communication.

\section{Performance Appraisal Satisfaction Cultivates Employee Performance}

Satisfaction with the appraisal process is regarded as one of the most consequential reactions to performance appraisal (Giles \& Mossholder, 1990). Performance appraisal satisfaction is conceptualised as whether the employees are "satisfied" with the organisation's appraisal process (Miller, 2001). Prior studies by Kuvaas (2006) asserted that employee satisfaction on performance appraisal determined their work performance. It means a properly managed performance appraisal will lead to high employees' satisfaction, and it sequentially elevates high work performance. Satisfaction with performance appraisal is necessary because it mediates the interactions between performance appraisal justice and results. According to the literature, when employees' choices are made equitably, it results in a psychological agreement favourably associated with PA satisfaction. Belsito \& Reutzel (2020) proved that employee reviews are positively received when employees perceive PA as procedural. Furthermore, Modipane et al. (2019) found that providing employees with enough and precise information and communicating with them habitually makes employees satisfied than not providing the information.

Koopmans et al. (2011) theorized employee performance into four dimensions, it consists of task performance (TP), contextual performance (CP), adaptative performance (AP), and counterproductive work behaviour (CWB). Task performance explained as a competency or capability to do the core or central tasks of the job, which includes knowledge of planning and coordinating work, work quality, results-oriented work, and the capacity to work efficiently. Contextual performance refers to the behaviours that promote the organisational, sociological, and psychological context wherein the technical core would operate, such as showing effort, enabling peer and team performance, collaborating, and communicating. On the other hand, adaptative performance occurs when a person adjusts to their work function or surroundings. Finally, counterproductive work behaviour as detrimental behaviour that undermines the organisation's well-being, like absenteeism, off-task behaviour, theft and substance misuse, is counterproductive work behaviour.

Dahkoul (2018) stressed that employee performance could be improved by focusing on the aspects that substantially affect their performance, such as satisfaction. This direct to an understanding of the causal connection between performance and satisfaction. Asad khan et al. (2018) believe that every organisation's success and survival rely on employee output and directly on performance. This explains why the organisation seeks to enhance the ability of its employees because it is a primary factor to improve employee performance. Employee performance will bring progress to the survival and sustainability of an organisation. As per the earlier work of Diamantidis \& Chatzoglou (2019), employee performance must be increased to improve organisational performance. 
Volume 3 Issue 10 (December 2021) PP. 39-48 DOI 10.35631/AIJBES.310004

In line with varied literature, employee performance can be improved if the appraised individuals perceive their evaluations as accurate and just and are satisfied. From a psychological standpoint, employee satisfaction with their performance appraisal impacts their attitudes and behaviour toward the company. It is supported by Kuvaas (2006) that employee satisfaction with the performance appraisal is related to their attitude towards fairness, which positively impacts work performance. It is also parallel to Purwantoro \& Bagyo (2019) that portrayed a correlation between organisational justice and employee performance, whereby providing fair wages following employees' performance and treating employees fairly had resulted in improved employee performance. Another research conducted by Chen et al. (2020), reinforced that organisational justice can demonstrate a significant effect on employees' sense of belonging, which, in turn, affects their performance as it encourages the employees to work hard.

\section{Artificial Intelligence Shaping The Future Of Performance Appraisal To Enhance Employee Performance In Malaysia}

Due to this robust effect of satisfaction in performance appraisal on employee performance, it is necessary to augment the distinctive characteristic of justice in the performance appraisal for a transparent and fair evaluation. In view of recent advances in artificial intelligence (AI), studies show time has arrived for these technologies can easily be adapted and refined to enhance employee satisfaction in performance appraisal and boost employee performance (Chelliah, 2017). Consider how these can impact employee satisfaction in performance appraisal and boost employee performance and quality of work.

S. Shanmugam \& Garg (2015) described biases minimised by having an intelligent system that regularly monitors performance and provides employees and supervisors with a platform for frequent constructive discussions. Most importantly, all data can be captured, and with performance rules defined, the entire appraisal process would become more transparent and achieve better employee performance. AI can make predictions with the help of digital tools to generate suitable data to help HR practitioners improve workplace learning, reduce biases in candidate assessment and retain and motivate existing employees, thereby creating an employee-oriented culture (Gaur et al., 2019).

According to Fisher (2019), IBM's A.I.-powered performance management system, called Big Blue, displays how AI can augment human intelligence while accepting managers to apply their knowledge and judgment. For example, one type of recommendation IBM's system makes for when and how a manager should start actively encouraging an antsy employee to stay with the company. The algorithms then will recommend actions like training or awarding an overdue promotion to keep them from leaving. It will integrate with an employee position description module, allowing managers to pull data from the employees' position descriptions and insert it into the evaluation. As a result, they will identify and meet critical employees' needs and improve the performance of the organisations. It may also enable organisations to make better HR decisions based on objective information.

Even though Malaysian multinational companies benefit from drawing on foreign management 'software' and practices from their head offices in the HR area (Rowley \& Abdul-Rahman, 2007), it is a relatively new area of interest in Malaysia. Strohmeier (2020) revealed that there is so far no systematic HR research into smart HRM, and the term is still unfamiliar in HRM. Therefore, a conceptual framework on how AI can assist in intensifying performance appraisal satisfaction to improve employee performance is developed. This study will enrich the existing 
Volume 3 Issue 10 (December 2021) PP. 39-48 DOI 10.35631/AIJBES.310004

body of knowledge related to the influence of performance appraisal, employee performance, the influence of justice in performance appraisal and also utilisation of artificial intelligence in enhancing justice in performance appraisal. In congruence, the study will contribute to the existing knowledge by observing how Organizational Justice Theory may affect understanding performance appraisal in organisations. The significant contribution of the study is the linking of the dimensions of justice and artificial intelligence, which highlight the positive and negative consequences of employee performance, respectively. The AI in this study will indicate the influence of justice on employee performance, thereby making significant theoretical contributions to the organisational outlook. The proposed framework provides theoretical guidance and recommendations for the combination of performance appraisal and AI technology.

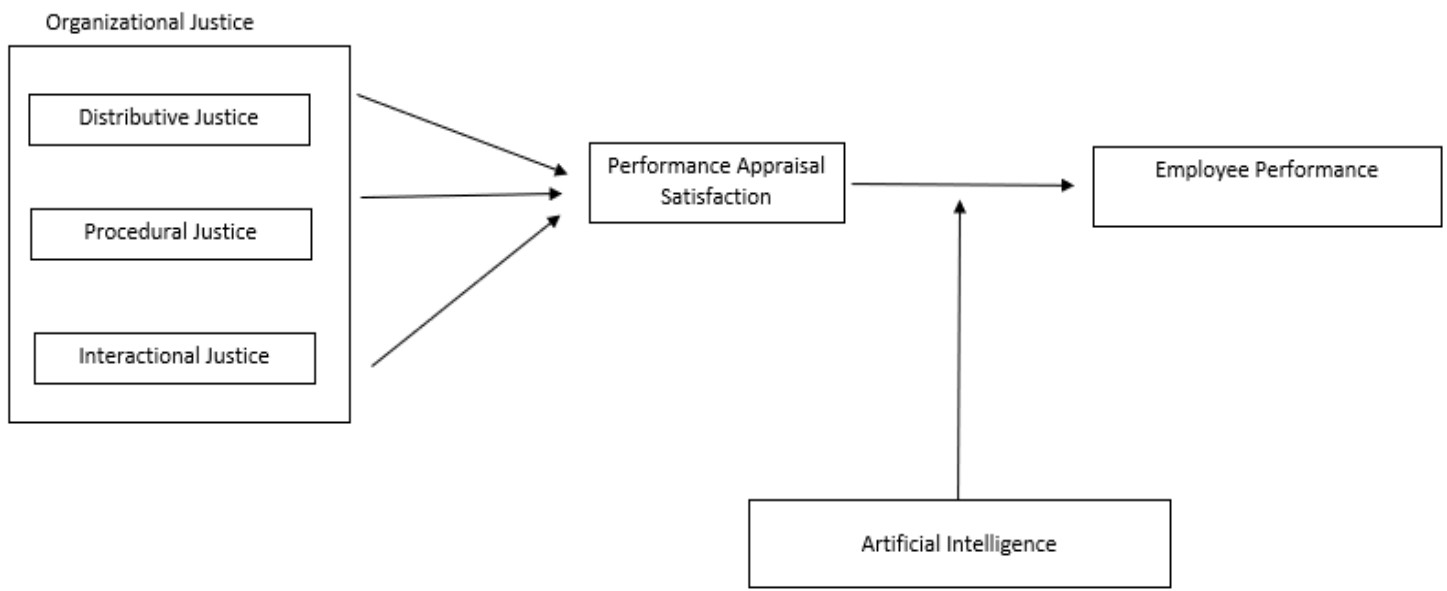

From the practical contribution point of view, the study results were expected to better understand the impact of employee performance by enhancing justice in performance appraisal. The study results will help organisations appreciate performance appraisal as a practical strategic approach and integrate human resource activities with business policies. This study will also improve in decision-making of employee performance appraisal. Artificial intelligence will assist in the decision-making assessment of performance appraisal to optimise employee contributions to the organisation. Further, the study results will also provide helpful information in the context of Malaysian multinational companies (MNCs) on the development of artificial intelligence in their performance appraisal. For human resource managers, the findings from the study could be used as guidelines in the development and implementation of artificial intelligence in their performance appraisal process. They will comprehend how organisational justice theory affects employee satisfaction toward performance appraisal and eventually affects their organisation's effectiveness and efficiency.

\section{Conclusion}

Justice play does not guarantee that all parties get what they seek. However, it provides the prospect of power being exercised under normative standards that protect the dignity of all those involved. Managers must understand that encouraging a just performance appraisal leads to a better scenario that positively impacts employee performance toward the organisation. In 
Volume 3 Issue 10 (December 2021) PP. 39-48 DOI 10.35631/AIJBES.310004

conclusion, this study attempted to examine the moderation role of AI in the relationship between performance appraisal satisfaction and employee performance. Artificial intelligence will assist businesses in making better decisions about retaining, developing, and motivating their workforce. The researchers believe that these discoveries could create new opportunities to shape the future of human resource management. Fundamentally, the researcher needs to evaluate what a truly discrimination-free performance appraisal would entail, and Organizational Justice Theory enables managers in making these challenging decisions.

\section{References}

Abdul Wahab, H. (2018). the Legal Context of Employment Discrimination in Malaysia. International Journal for Studies on Children, Women, Elderly and Disabled, 4(April), 119-124. https://www.researchgate.net/publication/324201240_THE_LEGAL_CONTEXT_OF _EMPLOYMENT_DISCRIMINATION_IN_MALAYSIA/citation/download

Agyare, R., Yuhui, G., Mensah, L., Aidoo, Z., \& Opoku Ansah, I. (2016). The Impacts of Performance Appraisal on Employees' Job Satisfaction and Organizational Commitment: A Case of Microfinance Institutions in Ghana. International Journal of Business and Management, 11(9), 281. https://doi.org/10.5539/ijbm.v11n9p281

Asad khan, M., Binti Ismail, F., Yusoff, R., Hussain, A., \& Binti Mohd Yunus, F. (2018). The Impact of Performance Appraisal on Employee Job Performance in Public Sector Universities of Khyber Pakhtunkhwa, Pakistan. International Journal of Engineering \& Technology, 7(October), 544-548. www.sciencepubco.com/index.php/IJET

Belsito, C. A., \& Reutzel, C. R. (2020). SME employee performance appraisal formalization and trust in leadership change. International Journal of Organizational Analysis, 28(2), 434-456. https://doi.org/10.1108/IJOA-07-2019-1832

Bies, R. J., \& Shapiro, D. L. (1987). Interactional fairness judgments: The influence of causal accounts. Social Justice Research, 1(2), 199-218. https://doi.org/10.1007/BF01048016

Bobocel, D. R. (2021). Current directions in organizational justice. Canadian Journal of Behavioural Science / Revue Canadienne Des Sciences Du Comportement, 53(2), 98105. https://doi.org/10.1037/cbs0000258

Chabowski, B. R., \& Mena, J. A. (2017). A review of global competitiveness research: Past advances and future directions. Journal of International Marketing, 25(4), 1-24. https://doi.org/10.1509/jim.16.0053

Chelliah, J. (2017). Will artificial intelligence usurp white collar jobs? Human Resource Management International Digest, 25(3), 1-3. https://doi.org/10.1108/HRMID-112016-0152

Chen, T., Hao, S., Ding, K., Feng, X., Li, G., \& Liang, X. (2020). The impact of organizational support on employee performance. Employee Relations, 42(1), 166-179. https://doi.org/10.1108/ER-01-2019-0079

Cojuharenco, I., \& Patient, D. (2013). Workplace fairness versus unfairness: Examining the differential salience of facets of organizational justice. Journal of Occupational and Organizational Psychology, 86(3), 371-393. https://doi.org/10.1111/joop.12023

Colquitt, J. A. (2001). On the dimensionality of organizational justice: A construct validation of a measure. Journal of Applied Psychology, 86(3), 386-400. https://doi.org/10.1037/0021-9010.86.3.386

Colquitt, J. A. (2012). Organizational Justice. The Oxford handbook of organizational psychology. Oxford University Press. https://doi.org/http://media.terry.uga.edu/socrates/publications/2015/01/Colquitt2012. pdf 
Volume 3 Issue 10 (December 2021) PP. 39-48 DOI 10.35631/AIJBES.310004

Colquitt, J. A., \& Zipay, K. P. (2015). Justice, Fairness, and Employee Reactions. Annual Review of Organizational Psychology and Organizational Behavior, 2(December 2014), 75-99. https://doi.org/10.1146/annurev-orgpsych-032414-111457

Cropanzano, R., Bowen, D. E., \& Gilliland, S. W. (2007). The management of organizational justice. Academy of Management Perspectives, 21(4), 34-48. https://doi.org/10.5465/AMP.2007.27895338

Dahkoul, Z. M. (2018). The determinants of employee performance in Jordanian organizations. Pressacademia, 5(1), 11-17. https://doi.org/10.17261/Pressacademia.2018.780

Diamantidis, A. D., \& Chatzoglou, P. (2019). Factors affecting employee performance: an empirical approach. International Journal of Productivity and Performance Management, 68(1), 171-193. https://doi.org/10.1108/IJPPM-01-2018-0012

Dundon, T., \& Rafferty, A. (2018). The (potential) demise of HRM? Human Resource Management Journal, 28(3), 377-391. https://doi.org/10.1111/1748-8583.12195

Ekom Etim, A., Uzonna, I., Steve C., W., \& Chibuike E., N. (2018). Social Media Usage and Firm Performance: Reflections from the Nigerian Telecommunication Sector. INTERNATIONAL JOURNAL OF MANAGEMENT SCIENCE AND BUSINESS ADMINISTRATION, 4(6), 7-16. https://doi.org/10.18775/ijmsba.1849-56645419.2014.46.1001

Fisher, A. (2019, July). An Algorithm May Decide Your Next Pay Raise. Fortune. https://doi.org/https://fortune.com/2019/07/14/artificial-intelligence-workplace-ibmannual-review/

Gaur, B., Shukla, V. K., \& Verma, A. (2019). Strengthening People Analytics through Wearable IOT Device for Real-Time Data Collection. 2019 International Conference on Automation, Computational and Technology Management, ICACTM 2019, 555560. https://doi.org/10.1109/ICACTM.2019.8776776

Giles, W. F., \& Mossholder, K. W. (1990). Employee Reactions to Contextual and Session Components of Performance Appraisal. Journal of Applied Psychology, 75(4), 371377. https://doi.org/10.1037/0021-9010.75.4.371

Greenberg, J. (1986). Determinants of Perceived Fairness of Performance Evaluations. Journal of Applied Psychology, 71(2), 340-342. https://doi.org/10.1037/0021-9010.71.2.340

Greenberg, J. (1987). A Taxonomy of Organizational Justice Theories. The Academy of Management Review, 12(1), 9. https://doi.org/10.2307/257990

Hashim, R. A., Akmal Binti Ghazali, Z., \& Jamaludin, A. (2015). Past Performance Evaluation is the First Step toward the Future: A Case Study of a Performance Management System in a Malaysian Multi-National Company. American Journal of Economics, 5(2), 278284. https://doi.org/10.5923/c.economics.201501.36

Kim, T., \& Holzer, M. (2016). Public Employees and Performance Appraisal: A Study of Antecedents to Employees' Perception of the Process. Review of Public Personnel Administration, 36(1), 31-56. https://doi.org/10.1177/0734371X14549673

Koopmans, L., Bernaards, C. M., Hildebrandt, V. H., Schaufeli, W. B., de Vet Henrica, C. W., \& van der Beek, A. J. (2011). Conceptual frameworks of individual work performance: A systematic review. Journal of Occupational and Environmental Medicine, 53(8), 856-866. https://doi.org/10.1097/JOM.0b013e318226a763

Krishnan, R., Ahmad, N. A. F. binti, \& Haron, H. (2018). The Effect of Employeesâ€ $€^{\mathrm{TM}}$ Perceived Fairness of Performance Appraisal Systems on Employeesâ€ $€^{\mathbf{T M}}$ Organizational Commitment. International Journal of Academic Research in Business and Social Sciences, 8(3), 466-483. https://doi.org/10.6007/ijarbss/v8-i3/3941 
Volume 3 Issue 10 (December 2021) PP. 39-48 DOI 10.35631/AIJBES.310004

Kuvaas, B. (2006). Performance appraisal satisfaction and employee outcomes: Mediating and moderating roles of work motivation. International Journal of Human Resource Management, 17(3), 504-522. https://doi.org/10.1080/09585190500521581

Miller, J. S. (2001). Self-monitoring and performance appraisal satisfaction: An exploratory field study. Human Resource Management, 40(4), 321-332. https://doi.org/10.1002/hrm.1022

Modipane, P. I., Botha, P. A., \& Blom, T. (2019). Employees' perceived effectiveness of the performance management system at a north-west provincial government department. South African Journal of Childhood Education, 17, 1-12. https://doi.org/10.4102/sajhrm.v17i0.1081

Niehoff, B. P., \& Moorman, R. H. (1993). Justice as a Mediator of the Relationship Between Methods of Monitoring and Organizational Citizenship Behavior. Academy of Management Journal, 36(3), 527-556. https://doi.org/10.5465/256591

Potgieter, I. L., Coetzee, M., \& Ximba, T. (2017). Exploring career advancement challenges people with disabilities are facing in the South African work context. SA Journal of Human Resource Management, 15(0), 1-11. https://doi.org/10.4102/sajhrm.v15i0.815

Purwantoro, H., \& Bagyo, Y. (2019). Citizenship organizational behavior ability to increase the effect of organizational climate, work motivation, and organizational justice on employee performance. Management and Economics Journal (MEC-J), 3(2), 195. https://doi.org/10.18860/mec-j.v3i2.7455

Rahahleh, A. H., Alabaddi, Z. A., \& Moflih, M. A. (2019). The Impact of Performance Appraisal on Employee Performance in Banks Operating in the South of Jordan. International Journal of Human Resource Studies, 9(4), 77. https://doi.org/10.5296/ijhrs.v9i4.15317

Rana, S., Pant, D., \& Chopra, P. (2019). Work Engagement and Individual Work Experience: Research Findings and An Agenda for Employee Relationships. Journal of Emerging Technologies and Innovative Research, 6(5), 17-32. https://doi.org/10.13140/RG.2.2.12846.56644

Rasiah, R., \& Krishnan, G. (2020). Industrialization and Industrial Hubs in Malaysia. In A. Oqubay \& J. Y. Lin (Eds.), The Oxford Handbook of Industrial Hubs and Economic Development (pp. 700-722). Oxford University Press. https://doi.org/10.1093/oxfordhb/9780198850434.013.36

Roberson, Q. M., \& Stewart, M. M. (2006). Understanding the motivational effects of procedural and informational justice in feedback processes. British Journal of Psychology, 97(3), 281-298. https://doi.org/10.1348/000712605X80146

Roch, S. G., Shannon, C. E., Martin, J. J., Swiderski, D., Agosta, J. P., \& Shanock, L. R. (2019). Role of employee felt obligation and endorsement of the just world hypothesis: A social exchange theory investigation in an organizational justice context. Journal of Applied Social Psychology, 49(4), 213-225. https://doi.org/10.1111/jasp.12578

Rowley, C., \& Abdul-Rahman, S. (2007). The management of human resources in Malaysia: Locally-owned companies and multinational companies. Management Revue, 18(4), 427-453. $\quad$ https://doi.org/http://hdl.handle.net/10419/78917 StandardNutzungsbedingungen:

Sandhu, M. A., Iqbal, J., Ali, W., \& Tufail, M. S. (2017). Effect of Employee Motivation on Employee Performance. Journal of Business and Social Review in Emerging Economies, 3(1), 85-100. https://doi.org/10.26710/jbsee.v3i1.182

Shanmugam, M. (2019). Annual performance appraisals are outdated. https://doi.org/https://www.thestar.com.my/business/businessnews/2019/12/14/annual -performance-appraisals-are-outdated

Copyright (C) GLOBAL ACADEMIC EXCELLENCE (M) SDN BHD - All rights reserved 
Volume 3 Issue 10 (December 2021) PP. 39-48 DOI 10.35631/AIJBES.310004

Shanmugam, S., \& Garg, L. (2015). Model employee appraisal system with artificial intelligence capabilities. Journal of Cases on Information Technology, 17(3), 30-40. https://doi.org/10.4018/JCIT.2015070104

Shaukat, H., Ashraf, N., \& Ghafoor, S. (2015). Impact of Human Resource Management Practices on Employees Performance. 23(2), 329-338. https://doi.org/10.5829/idosi.mejsr.2015.23.02.22117

Strohmeier, S. (2020). Smart HRM - a Delphi study on the application and consequences of the Internet of Things in Human Resource Management. The International Journal of Human Resource Management, 31(18), 2289-2318. https://doi.org/10.1080/09585192.2018.1443963

Tomczak, D. L., Lanzo, L. A., \& Aguinis, H. (2018). Evidence-based recommendations for employee performance monitoring. Business Horizons, 61(2), 251-259. https://doi.org/10.1016/j.bushor.2017.11.006

Warokka, A., Gallato, C. G., \& Moorthy, T. (2012). Does organizational justice in performance appraisal system affect work performance? Evidence from an emerging market. Innovation and Sustainable Competitive Advantage: From Regional Development to World Economies - Proceedings of the 18th International Business Information Management Association Conference, 4, 2292-2308. https://doi.org/10.5171/2012.159467 